\title{
PERANCANGAN PROGRAM APLIKASI PEMBELAJARAN IPA MATERI SISTEM PERNAPASAN BERBASIS MULTIMEDIA UNTUK SISWA SDLB BAGIAN B TUNA RUNGU MENGGUNAKAN OBJECT ORIENTED APPROACH
}

\author{
Diana Effendi \\ Fakultas Teknik, Program Studi Manajemen Informatika \\ Universitas Komputer Indonesia \\ Email: aprildidi2@yahoo.com \\ Bella Hardiyana \\ Fakultas Teknik, Program Studi Sistem Informasi \\ Universitas Komputer Indonesia \\ Email: bella@gmail.com \\ Iyan Gustiana \\ Fakultas Teknik, Program Studi Sistem Informasi \\ Universitas Komputer Indonesia \\ Email: likmis@yahoo.com
}

\begin{abstract}
ABSTRAK
Tunarungu, samahalnya dengan difabel yang lain yang merupakan warganegara Indonesia berhak memperoleh pendidikan. Seperti diketahui Anak Berkebutuhan Khusus (ABK) membutuhkan perhatian lebih untuk meningkatkan fokus terhadap proses belajar. Saat ini dalam kegiatan belajar mengajar di objek penelitian yaitu SDLB Bagian (B) Cidendo Bandung dilakukan secara konvensional, dimana guru menjelaskan materi pelajaran menggunakan buku sebagai alat bantu dalam pengajaran. Keterbatasan media alat bantu yang tepat untuk mengajaranak tuna rungu menjadi masalah bagi para guru untuk mampu menjelaskan materi pelajaran yang dibebankan kepada siswa. Terutama pada mata pelajaran IPA/Sains yang cukup komplek, contohnya materi sistem pernapasan pada manusia dan hewan sangat membutuhkan bantuan alat yang lebih ke arah visual. Untuk mengatasi hal tersebut, dalam penelitian ini dibuatlah rancangan program aplikasi alat bantu pembelajaran IPA/Sains untuk SDLB bagian B khususnya materi sistem pernapasan manusia dan hewan menggunakan metode penelitian Research Development, metode pendekatan berbasis objek (object-oriented approach), dengan alat bantu perancangan menggunakan Unified Modeling Language (UML) yaitu Use Case, Sequence Diagram, Class Diagram.Sedangkan model pengembangan sistem menggunakan prototype. Rancangan tersebut meliputi rancangan proses, rancangan user interface program aplikasi yang disesuaikan dengan aplikasi berbasis multimedia. Berdasarkan rancangan tersebut, nantinya diharapkan dapat diimplementasikan menggunakan software Adobe Flash Cs3 Proffesional yang berbasiskan multimedia, dimana dengan multimedia memungkinkan suatu materi yang tidak dapat disampaikan secara verbal atau kejadian, dapat direkayasa sedemikian rupa sehingga bisa disajikan dengan terperinci dan sangat menarik bagi siswa.
\end{abstract}

Kata kunci: anak berkebutuhan khusus (ABK), tunarungu, IPA/sains, sistem pernapasan manusia dan hewan.

\section{ABSTRACT}

Deaf, similar to other disabilities, which is an Indonesian citizen who has the right to education. As is known, Children with Special Needs $(A B K)$ requires more attention to increase the focus on the learning process. Currently, the teaching and learning activities in the research object is SDLB-B Cidendo Bandung done conventionally, in which the teacher explains the lesson to use the book as a tool in teaching. Limitations of the right media tools to teach deaf children to be a problem for teachers to explain the lesson to the students. Especially in science subjects / Science quite complex, for example lesson respiratory system in humans and animals in need of assistance is more powerful teaching tool that visually. To solve this problem, in this study then created the program design application tools science learning for SDLB-B, especially for subjects respiratory systems of humans and animals using a Research Development method, and method based approach (object-oriented approach), with design tools using Unified Modeling Language (UML) ie Use Case, Sequence Diagram, Class Diagram. The system development model using a prototype model. The designs were includes the design process, the design of the user interface of the application program that is adapted to multimedia-based applications. Based on the design, expected to be implemented using Adobe Flash CS3 Professional software-based 
multimedia, where the multimedia can make a lesson that can not be delivered verbally or events, can be engineered such that it can be presented with a detailed and very interesting for students

Keywords: children with special needs, deaf, science, respiratory system in humans and animals.

\section{PENDAHULUAN}

Seperti diketahui Anak Berkebutuhan Khusus (ABK) membutuhkan perhatian lebih untuk meningkatkan fokus terhadap proses belajar, dengan cara mengabaikan kekurangan yang dimiliki dan memaksimalkan potensi daya tangkap pada indera lainnya sehingga proses belajar yang tepat akan menghasilkan prestasi belajar yang memuaskan. Sebenarnya dengan melihat perkembangan TIK yang ada saat ini sangat besar peluang untuk dikembangkannya alat bantu ajar bagi ABK baik yang dikemas dalam bentuk audio, visual maupun memanfatkan internet.

Salah satu cara pemanfaatan TIK sebagai media ajar untuk ABK adalah dengan memanfaatkan multimedia. Salah satu inovasi dalam pembelajaran yaitu dengan pengintegrasian teknologi informasi dan komunikasi dalam bentuk multimedia interaktif [1]. Multimedia berasal dari dua kata, yaitu multi dan media. Multi berarti banyak dan media biasa diartikan alat untuk menyampaikan atau membuat sesuatu, perantaraan, alat pengantar, suatu bentuk komunikasi [4]. Keuntungan pembelajaran multimedia yaitu materi bahan ajar dapat disajikan lebih menarik dan siswa bisa berinteraksi dengan materi yang disajikan dengan cara memilih materi yang disajikan berbantuan keyboard maupun mouse. Sistem multimedia interaktif harus memenuhi kriteria yaitu: (1) berorientasi pada tujuan pembelajaran, (2) berorientasi pada pembelajaran individual, (3) berorientasi pada pembelajaran mandiri dan (4) berorientasi pada pembelajaran tuntas [2].

Multimedia merupakan media yang sangat baik untuk meningkatkan proses belajar dengan memberikan kesempatan bagi para mahasiswa dalam mengembangkan keterampilan, mengidentifikasi masalah, mengorganisasi, menganalisis, mengevaluasi, dan mengkomunikasikan informasi [3]. Selain itu, pembelajaran dengan multimedia memungkinkan materi yang tidak dapat disampaikan dengan verbal atau kejadian dapat direkayasa bisa disajikan dengan terperinci dan sangat menarik bagi siswa. Misalnya dalam materi Ilmu Pengetahuan Alam/ Sains, misalnya bagaimana menjelaskan ke siswa mengenai metamorfosis kehidupan kupu-kupu dari ulat sampai menjadi kupu-kupu, metabolism peredaran darah manusia atau bagaimana terjadinya gempa bumi bahkan terjadinya tsunami yang dapat disajikan secara visualisasi animasi. Penggunaan Teknologi dalam pembelajaran fisika lebih produktif dibandingkan dengan metode tradisional seperti ceramah dan demonstrasi [4].

Pembuatan materi ajar berbasis multimedia untuk ABK yaitu memperhatikan grafis, animasi dan suara karena setiap ABK mempunyai karakteristik yang berbeda dan perlakuan pembelajaran yang berbeda tidak bisa disamakan ketika membuat materi ajar berbasis multimedia untuk anak normal [5]. Misalnya gangguan pendengaran sangat ringan (27-40dB), gangguan pendengaran ringan (41-55dB), gangguan pendengaran sedang (56-70dB), gangguan pendengaran berat (71-90dB), gangguan pendengaran ekstrem/tuli (di atas $91 \mathrm{~dB}$ ) berbeda teknik pengaturan suara di animasinya [5,6]. Suatu sistem multimedia interaktif dapat memberikan materi pembelajaran yang tingkat kesulitannya sesuai dengan kemampuan pengguna, dan cara mempresentasikan materi pembelajarannya sesuai dengan gaya belajar pengguna [3].

Agar program aplikasi yang akan dibangun sesuai dengan kebutuhan siswa tuna rungu, maka diperlukan rancangan aplikasi yang memfokuskan visual animasi baik rancangan proses maupun rancangan user interface. Seperti diketahui siswatuna rungu dalam proses belajar kesulitan menggunakan indera pendengaran yang merupakan organ vital dalam proses belajar pembelajaran, mereka dapat berkomunikasi dengan cara melihat gerakbibir (lip reading) lawan bicaranya dengan istilah "pemata" [6]. Oleh karena itu, diperlukan perancangan program aplikasi yang dapat memenuhi kebutuhan siswa tuna rungu maupun guru pengajar. Penelitian ini memfokuskan bagaimana merancang program aplikasi pembelajaran IPA/Sains untuk materi sistem pernafasan manusia dan hewan berbasis multimedia dengan memperhatikan interaktif user dengan yang digunakan di dalam pembelajaran.

Batasan dalam penelitian ini sebagai berikut:

a. Materi yang dibahas dalam penelitian merupakan materi pengajaran IPA/Sains untuk siswa SDLB Bagian B tuna rungu kelas $\mathrm{V}$, dengan pertimbangan dari guru pengajar bahwa materi IPA/Sains yang sangat kompleks dan membutuhkan visualisasi terdapat di kelas V. Namun, hal ini tidak menutup kemungkinan tingkatan SDLB yang lain dapat menggunakan program ini nantinya.

b. Hanya materi sistem pernafasan manusia dan hewan yang akan dibahas, berdasarkan hasil wawancara dengan guru pengajar.

c. Materi yang tersaji di program aplikasi berdasarkan materi yang ada di SDLB Bagian B Cicendo, 
Bandung yang menggunakan KURTILAS 2013.

d. Hasil akhir dari penelitian tersebut hanya sampai perancangan yang meliputi perancangan sistem program aplikasi dan rancangan user interface program aplikasi.

\section{METODE PENELITIAN}

Metoda Penelitian yang digunakan adalah penelitian pengembangan (Development Research), karena bertujuan untuk mengembangkan suatu produk berdasarkan kebutuhan dari suatu penelitian yang dilakukan sebelumnya. Pengembangan yang dilakukan adalah membuat rancangan aplikasi multimedia yang interaktif. Untuk maksud tersebut diperlukan metode pengumpulan data, model pengembangan sistem dan metode pendekatan sistem.

\subsection{Pengumpulan Data}

Mengenai teknik atau metode pengumpulan data yang penulis lakukan terhadap objek penelitian adalah dengan teknik observasi dan interview/wawancara.

1) Teknik Observasi

Dilakukan dengan mengamati objek penelitian baik secara dekat maupun jauh tanpa menyentuh langsung objek penelitian tersebut. Adapun rincian kegiatan yang dilakukan dengan menggunakan teknik observasi ini diantaranya sebagai berikut mengamati proses terkait kegiatan pembelajaran IPA/Sains yang ada saat ini, dimana masih menggunakan metode pembelajaran secara konvensional.

2) Teknik Interview / Wawancara

Melakukan percakapan dengan narasumber atau orang-orang yang terlibat langsung dengan sistem di lingkungan objek penelitian. Interview ini dilakukan baik secara formal maupun informal. Kebanyakan wawancara dilakukan secara informal dengan tujuan untuk menciptakan suasana yang nyaman dan santai sehingga user dan penulis selaku pengembang sistem dalam kasus ini bisa saling memahami kebutuhan sistem secara menyeluruh. User disini adalah guru pembina IPA/Sains.

\subsection{Model Pengembangan Sistem}

Model pengembangan sistem yang digunakan penulis pada penelitian ini yaitu model prototype. Adapun alasan memilih model ini dalam penelitian ini yaitu keinginan user sering berubah selama pembangunan sistem ini. Namun, pembangunan sistem ini telah dibatasi sampai tahap tertentu sesuai kesepakatan dengan user.

\subsection{Metode Pendekatan Sistem}

Metode pendekatan yang dipakai penulis untuk pembangunan sistem informasi ini yaitu memilih metode pendekatan berbasis objek (object-oriented approach). Alasan memilih metode pendekatan ini adalah sebagai berikut:

1) Berhubung kebutuhan masukan data dan proses tidak dapat didefinisikan dengan baik, maka tingkah laku objek yang terlibat dalam sistem ini menjadi pusat perhatian.

2) Hasil analisis di tempat penelitian, sistem ini lebih baik dibangun dengan metode object-oriented karena fokus pada interaksi antar objek dengan tidak memperlihatkan proses yang terjadi. Pemodelan sistem lebih mudah dan jelas terlihat jika digambarkan dengan metode objectoriented.

Sedangkan alat (tools) yang digunakan untuk memodelkan program aplikasi ini yaitu menggunakan UML, pemodelan bisnis (business modeling) dapat digambarkan dengan detail hubungan antara proses bisnis dengan user. Selanjutnya perancangan perangkat lunak sampai tahap implementasi secara detail digambarkan oleh masing-masing kategori diagram yang ada dalam UML. Dengan demikian, user bisa dengan mudah memahami mekanisme sistem secara keseluruhan. Sedangkan bagi pengembang sistem, memudahkan dalam pembangunan perangkat lunaknya karena cukup memperhatikan interaksi antara objek-objek dalam sistem. 


\section{HASIL PENELITIAN DAN PEMBAHASAN}

\subsection{Analisis User Requiment}

Sebelum melakukan perancangan program aplikasi media pembelajaran dalam penelitin ini, terlebihdahuludilkukanidentifikasi kebutuhan user. User yang dimaksuddisini adalah guru pengajar IPA/Sains dan siswa tuna rungukhususyasiswa kelas V. Bersarkan hasil wawancara dengan user mengenai kepuasanpengguna terhadap program aplikasi yang telah dibangun sebelumnya di Program IbM SDLB Bagian B. Program aplikasi yang telah dibuat masih memiliki kekurangan yaitu [7]:

1) Materi ajar IPA untuk SDLB Bagian B hanya untuk materi Sistem PeredaranDarahManusia dan Fotosintesis Pada Tumbuhan, tidak menyeluruh semua materi bahan ajar IPA/Sains yang ada. Pada aplikasi tersebut, belum dilengkapi bahasa isyarat untuk siswa.

2) Program aplikasi tersebut belum dilengkapi soal latihan materi ajar IPA/Sains untuk mengevaluasi sejauh mana kemampuan siswa dalam memahami materi yang disajikan.

Hasil penelitian sebelumnya sudah sangat membantu para guru pengajar dalam menjelaskan materi tersebut dan siswaantusias dalam mengikuti pelajaran. Selain itu tingkat pemahamansiswa setelah mengikuti materi yang telah dibuat sangat tinggi. Hal ini terbukti dari hasil evaluasi yang cukup bagus yang diadakan oleh guru terkait materi tersebut. Saat ini program aplikasi hasil penelitian sebelumnya, telah digunakan dalam kegiatan pembelajaran IPA/Sains di SDLB Cicendo Bandung dan SDLB Permata Hati Sumedang. Namun, pihak SDLB masih merasa kurang cakupan materi yang ada di program aplikasi tersebut dan meminta untuk dikembangkan lebih lanjut.

\subsection{Diagram Perancangan}

\subsubsection{Use Case Diagram}

Use case diagram menggambarkan kebutuhan sistem dari sudut pandang user, dimana memperlihatkan hubungan antara actor dengan use case dalam sistem. Dalam rancangan ini terdapat 2 actor yaitu siswa dan guru. Sedangkan use case dalam rancangan ini meliputi pembelajaran alat pernapasan, evaluasi pembelajaran alat pernapasan, refleksi pembelajaran alat pernapasan.

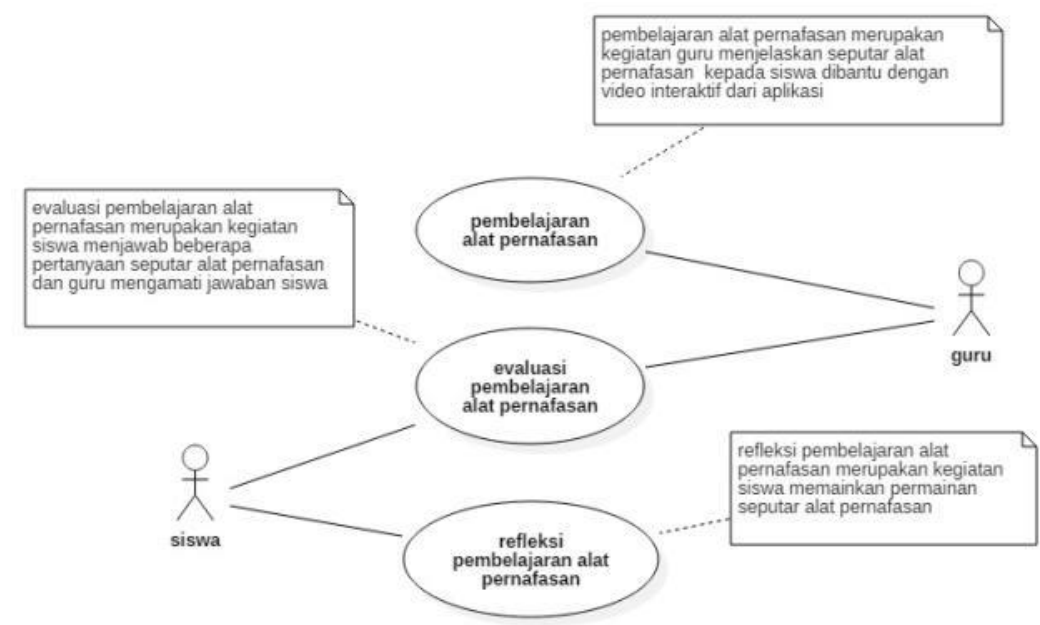

Gambar 2. Use Case Sistem

\subsubsection{Sequence Diagram}

Sequence diagram mendeskripsikan urutan pesan yang muncul diantara sekumpulan objek. Urutan dan waktu objek dengan jelas digambarkan. Pesan dalam sequence diagram mungkin memiliki parameter. Pesan bisa saja sinkronis atau bisa juga tidak sinkronis. 


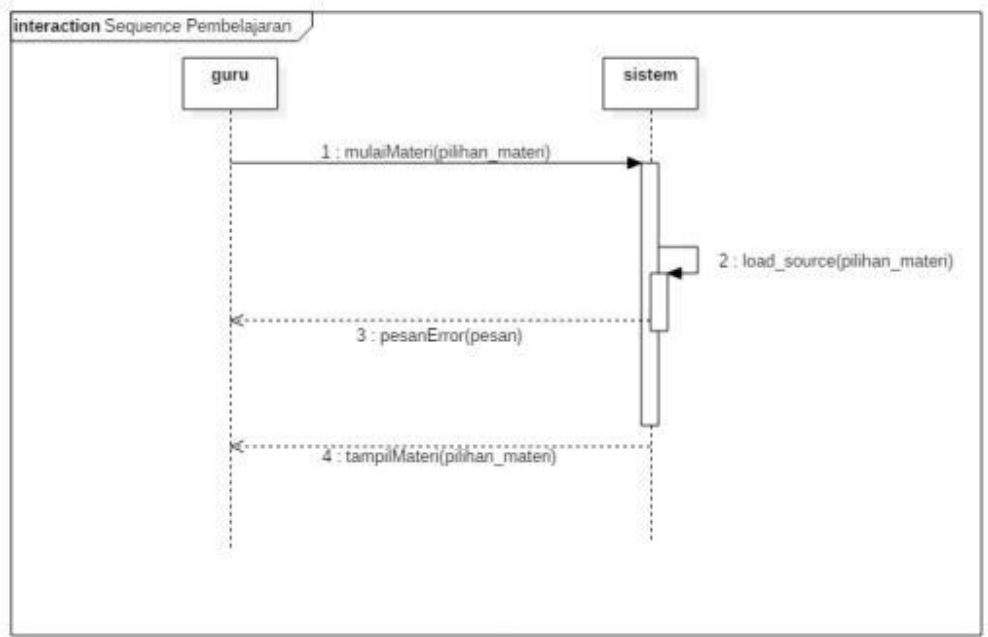

Gambar 3. Sequence Pembelajaran

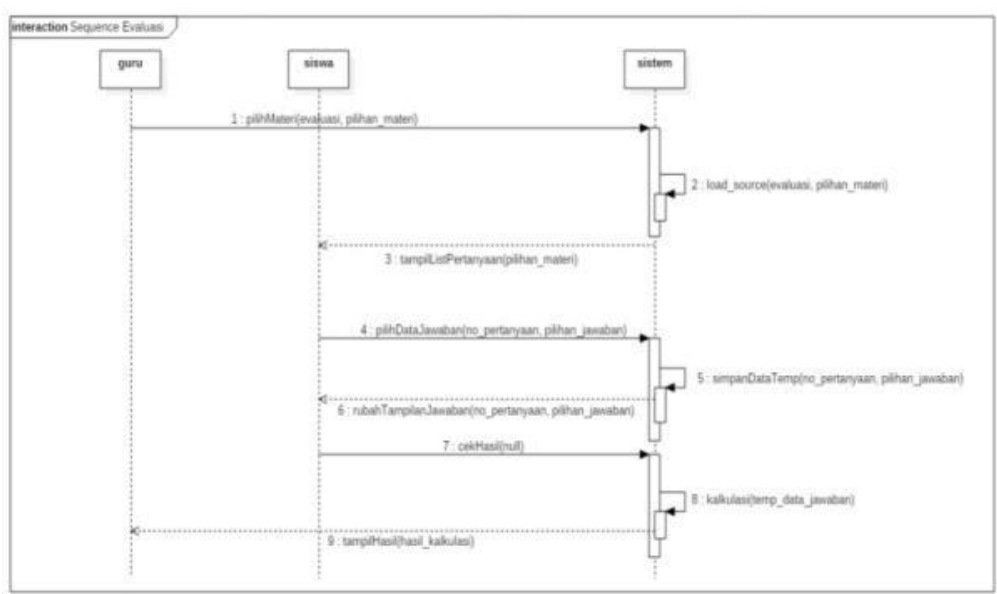

Gambar 4. Sequence Evaluasi

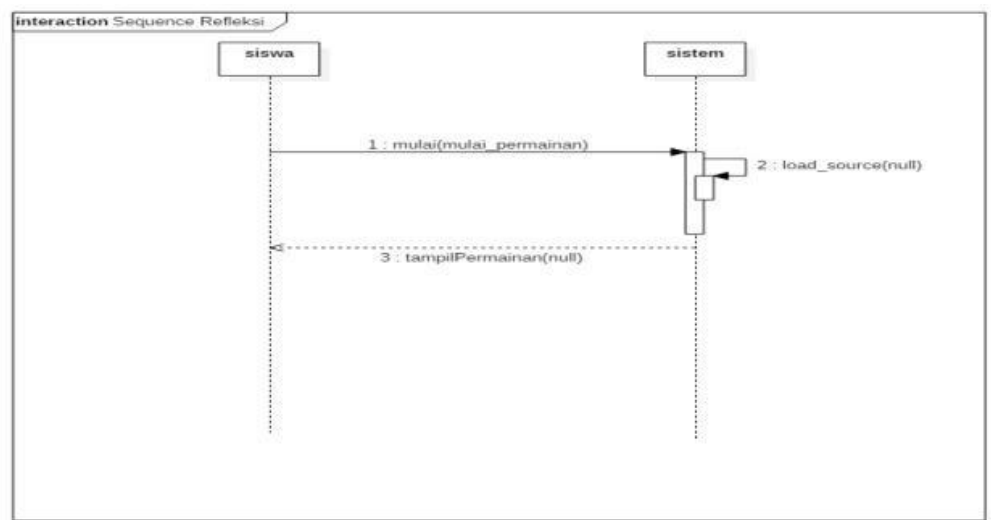

Gambar 5. Sequence Refleksi

\subsubsection{Class Diagram}

Class diagram terdiri dari kelas dan hubungan antar kelasnya. Class diagram menggambarkan struktur dari suatu sistem. Class dapat mewakili informasi, produk, dokumen, atau organisasi. Kelas dalam class diagram dihubungkan melalui asosiasi, bisa dengan agregasi, komposisi, generalisasi dan dependensi. 


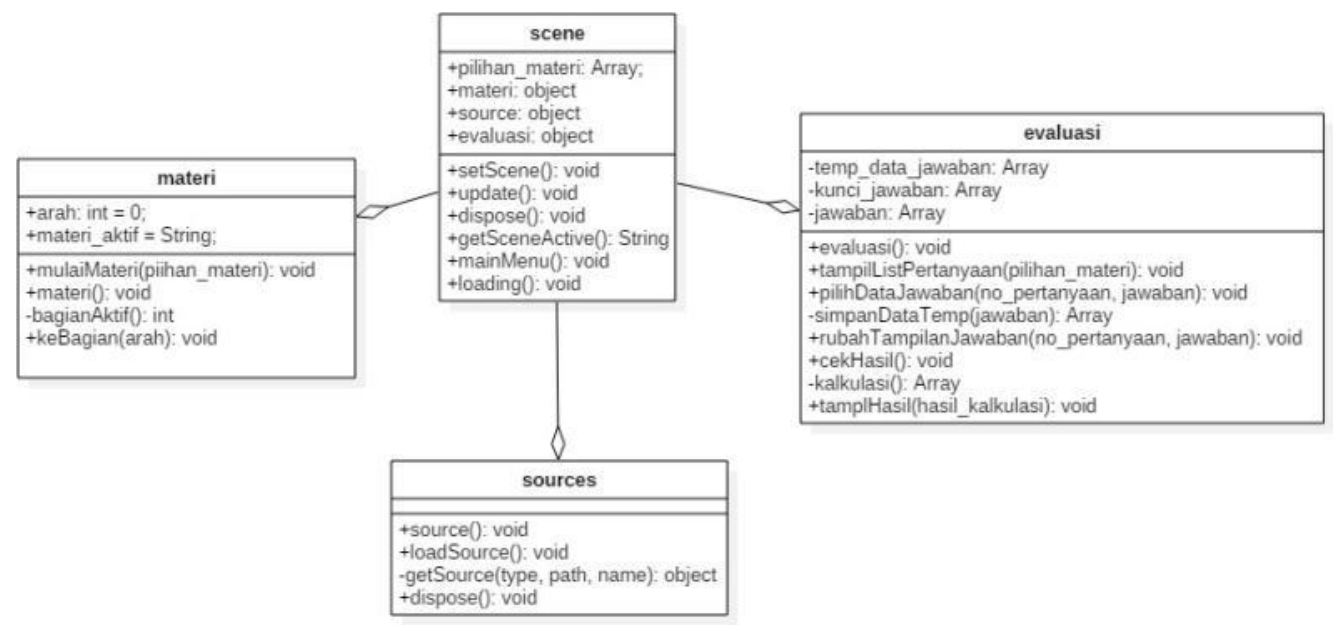

Gambar 6. Class Diagram Pembelajaran dan Evaluasi

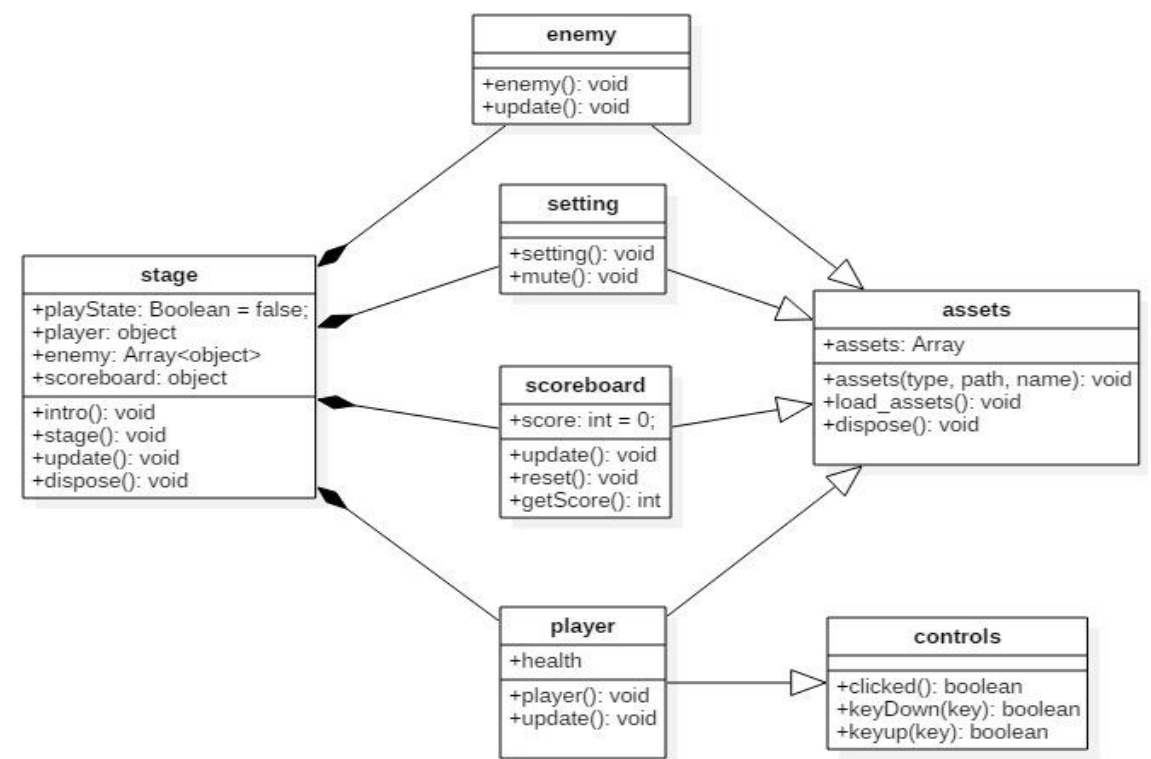

Gambar 7. Class Diagram Refleksi Pembelajaran

\subsection{Rancangan User Interface Program Aplikasi}

Berikut akan dipaparkan rancangan user interface program aplikasi pembelajaran IPA/SAINS materi sistem pernapasanmanusia dan hewan untuk siswa SDLB tuna rungu bagian B.

\subsubsection{Halaman Utama Program}

Pada halaman utama program aplikasi pembelajaran sistem pernapasan ini disajikan tiga pilihan bagi user yaitu materi alat pernapasan pada manusia, hewan, game dan quiz. 


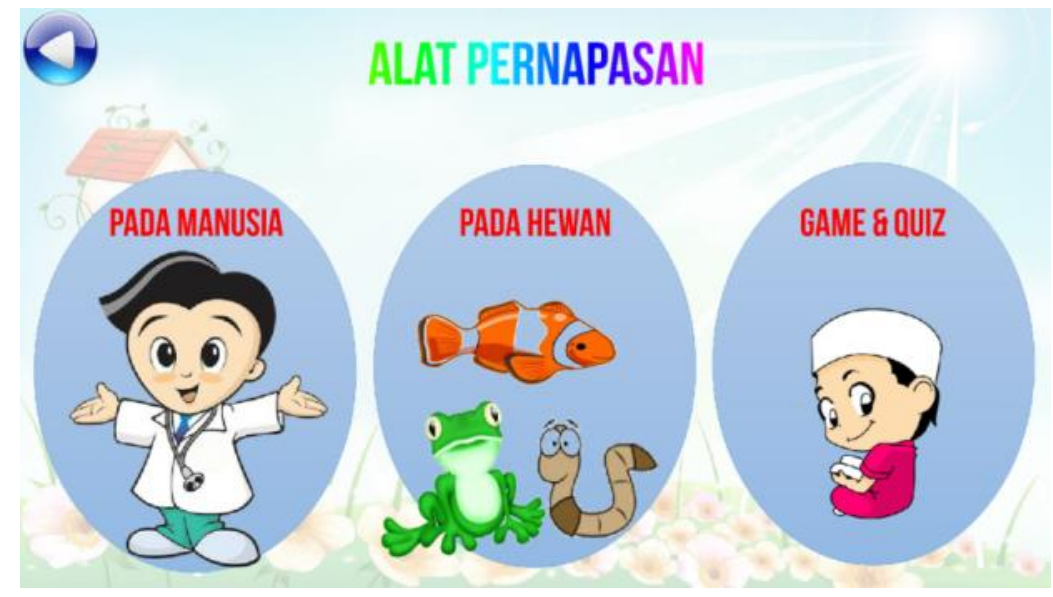

Gambar 8. Halaman Utama Program

\subsubsection{Halaman Pernapasan Pada Manusia}

Tampilan form yang tersaji pada gambar 9 akan ditampilkan, jika user memilih alat pernapasan pada manusia dengan klik tombol pada manusia (gambar 8).

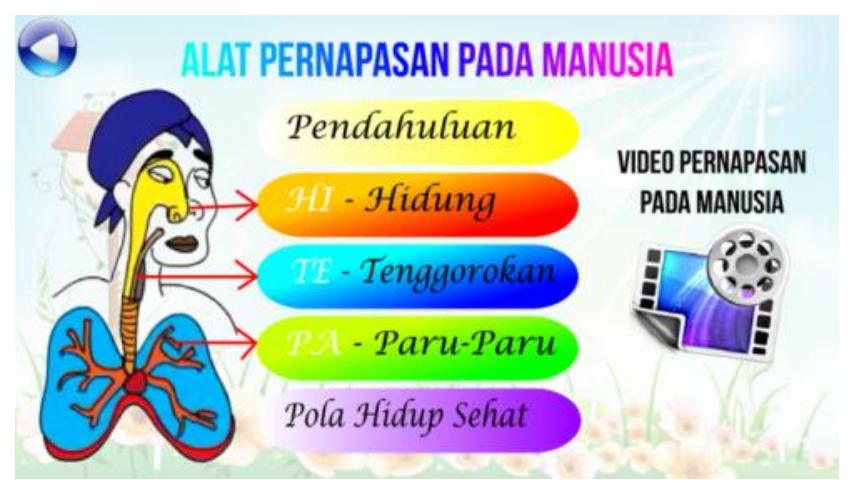

Gambar 9. Menu Pernapasan Pada Manusia

Sedangkan tampilan form untuk setiap tombol yang ada di menu alat pernapasanpadamanusiatersaji pada gambar 10 sampai dengan gambar 22. Di setiap form disajikan penjelasan materi sesuai dengan yang dipilih oleh user. Setiap penjelasan materi disajikan dengan menggabungkan audio, visual animasi.

Setiap form penjelasan alat pernapasan, disajikan tiga buahtombol pilihan yaitu pengertian, fungsi, dan bagian-bagian. Jika salah satu tombol tersebut di klik oleh user, maka akan tersaji penjelasan materi yang dimaksud.

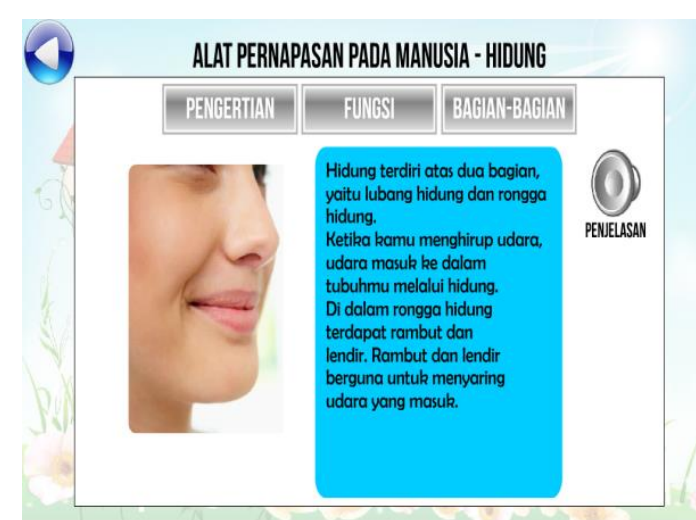

Gambar 10. Tampilan Klik Tombol Hidung (gambar 9)

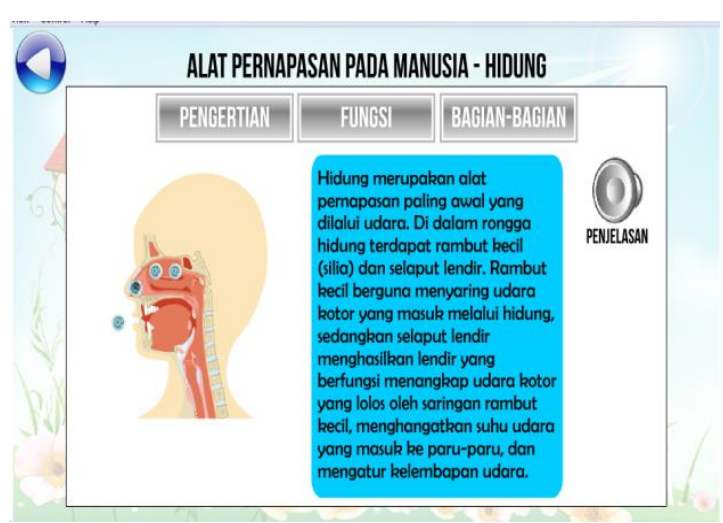

Gambar 11. Tampilan Klik Tombol Fungsi (Hidung) 


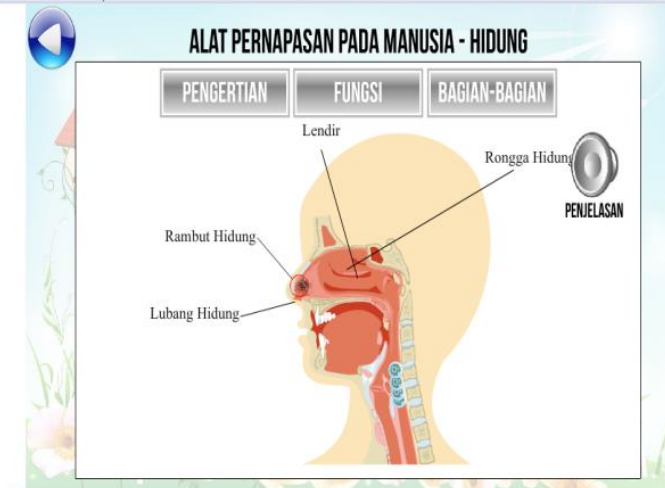

Gambar 12. Tampilan Klik Tombol Bagian-Bagian (Hidung)

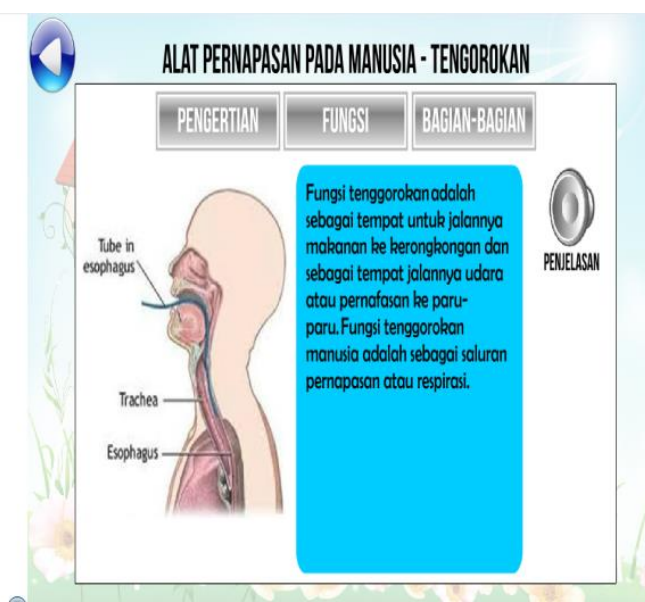

Gambar 14. Tampilan Klik Tombol Fungsi (tenggorokan)

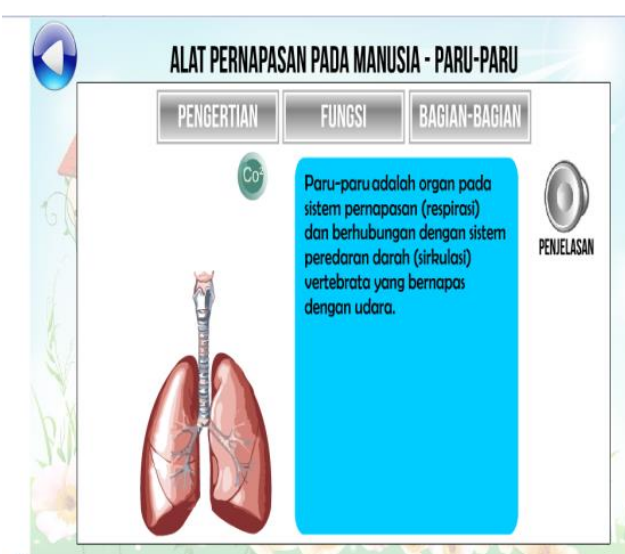

Gambar 16. Tampilan Klik Tombol Paru-Paru (gambar 9)

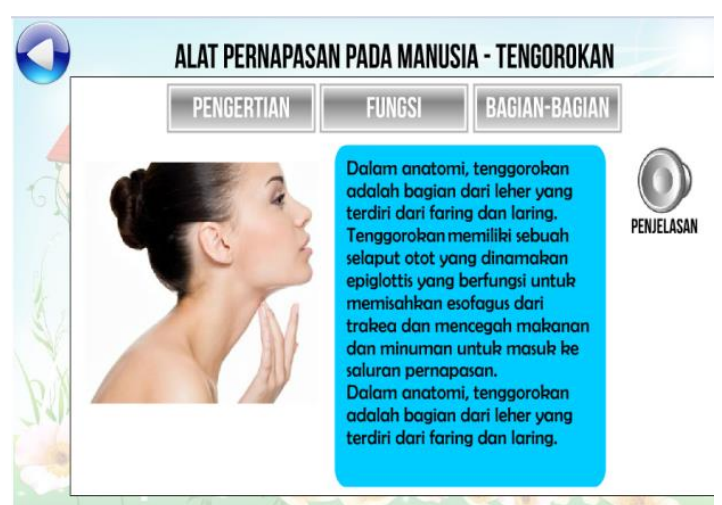

Gambar 13. Tampilan Klik Tombol Tenggorokan (gambar 9)

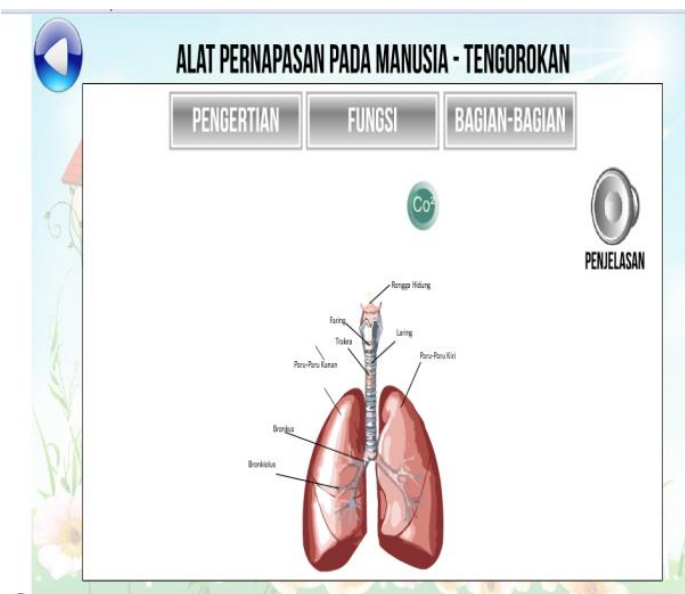

Gambar 15. Tampilan KlikTombol Bagian-Bagian (tenggorokan)

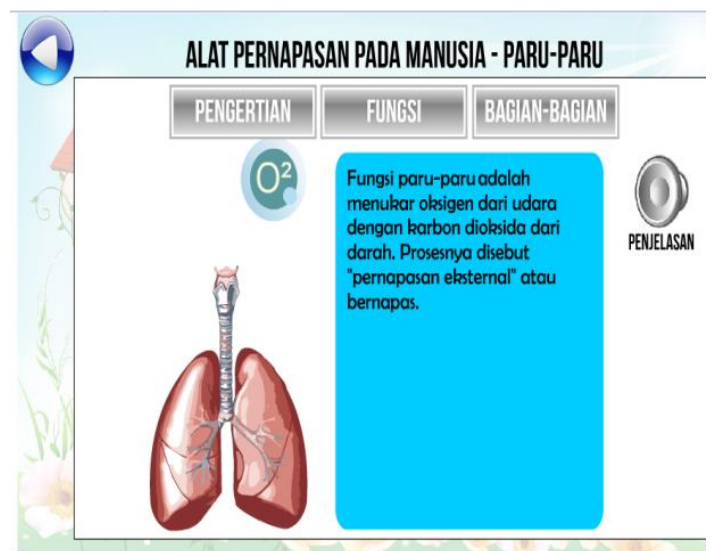

Gambar 17. Tampilan Klik Tombol Fungsi (ParuParu) 


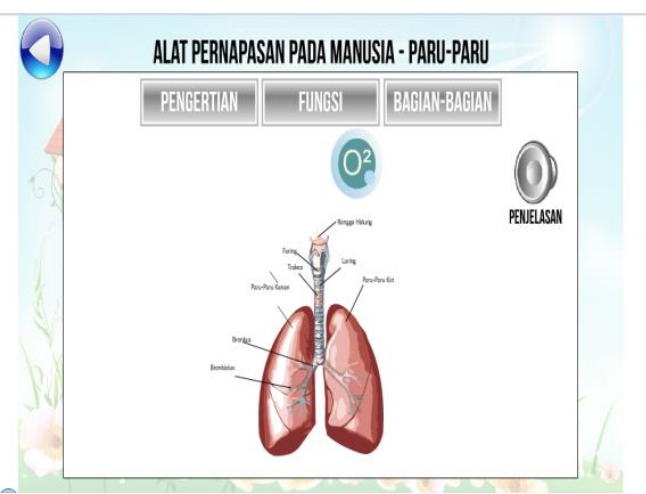

Gambar 18. Tampilan Klik Tombol Bagian-Bagian (Paru-Paru)

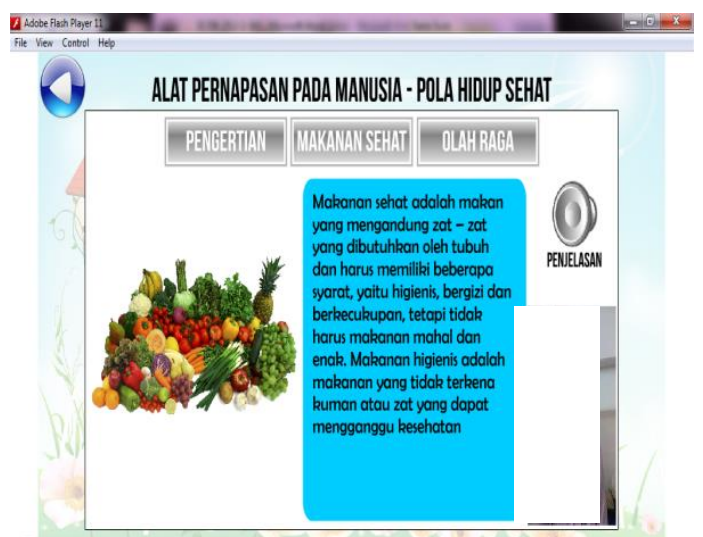

Gambar 20. Tampilan Klik Tombol Makanan Sehat

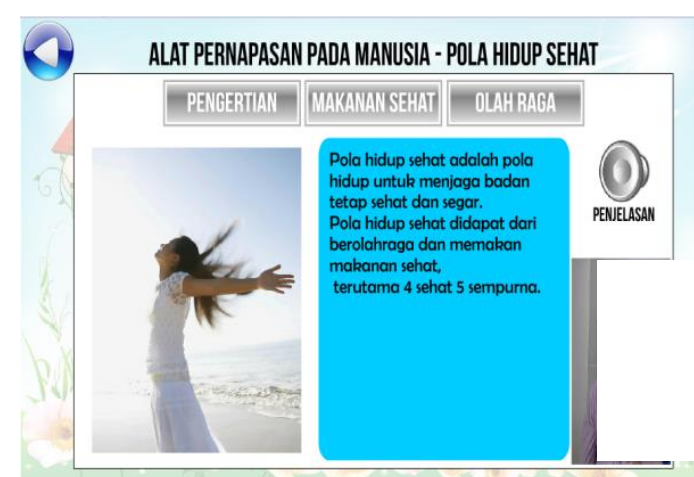

Gambar 19. Tampilan Klik Tombol Pola Hidup Sehat (gambar 9)

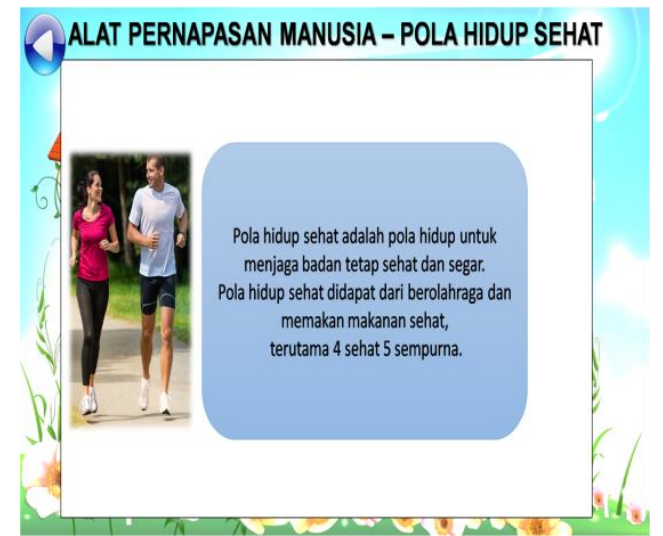

Gambar 21. Tampilan Klik Tombol Olah Raga

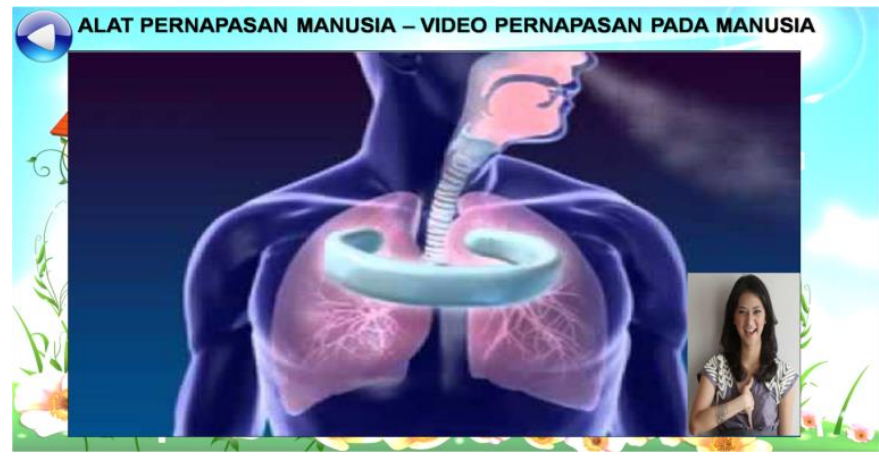

Gambar 22. Tampilan Klik Tombol Olah Raga

Untuk bahasa isyarat dari penjelasan yang disajikan terdapat di video pernapasan pada manusia dengan pertimbangan penjelasan lengkap terdapat dihalaman tersebut.

\subsubsection{Tampilan Menu Pernapasan Pada Hewan}

Tampilan form yang tersaji pada gambar 23 akan ditampilkan, jika user memilih alat pernapasan pada hewan dengan klik tombol pada hewan (gambar 8). Terdapat tiga contoh kelompok hewan yang disajikan yaitu katak, ikan, cacing dan burung. 


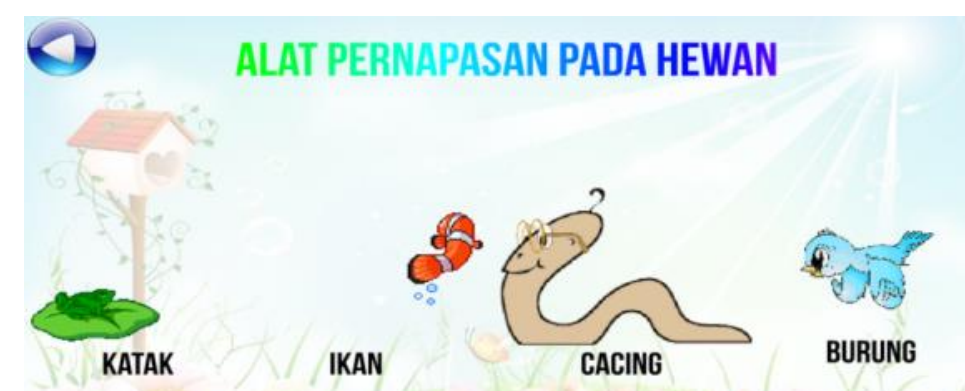

Gambar 23. Tampilan Form Alat Pernapasan Pada Hewan

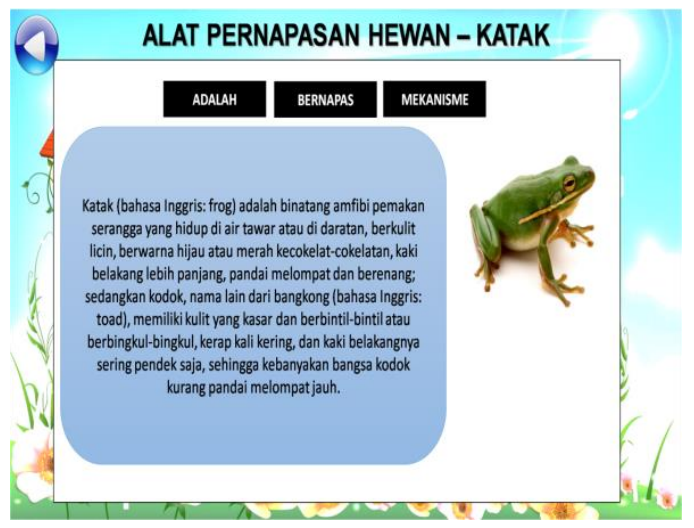

Gambar 24. Tampilan Klik Tombol Katak

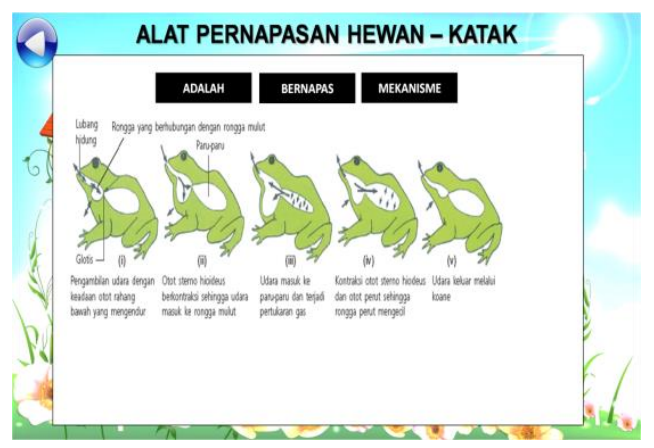

Gambar 26. Tampilan KlikTombol Mekanisme

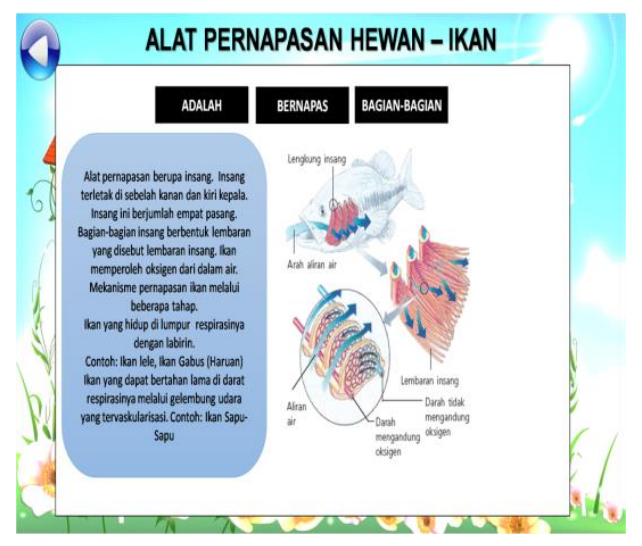

Gambar 28. Tampilan KlikTombol Bernapas

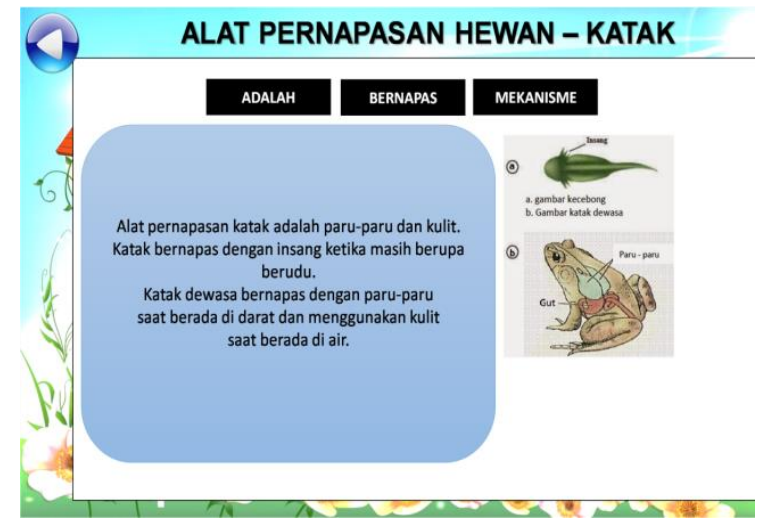

Gambar 25. Tampilan Klik Tombol Bernapas

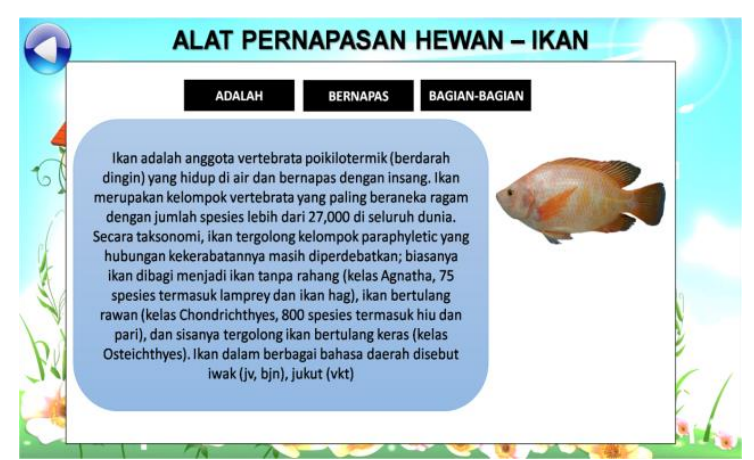

Gambar 27. Tampilan KlikTombol Ikan

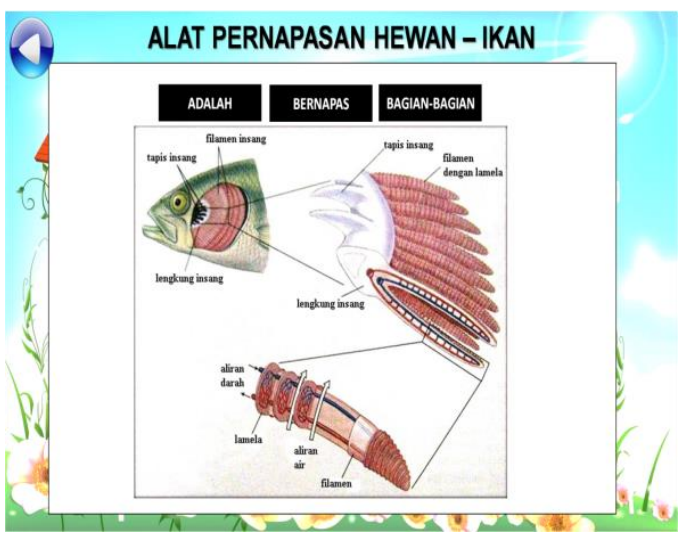

Gambar 29. Tampilan KlikTombol Bagian-Bagian 


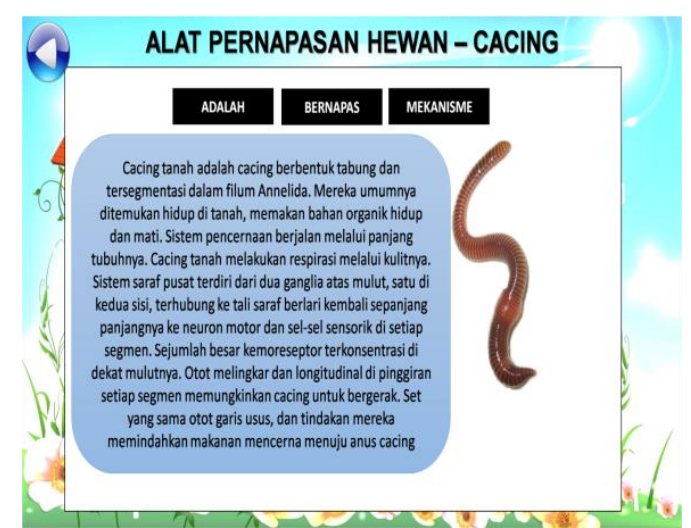

Gambar 30. Tampilan Klik Tombol Cacing

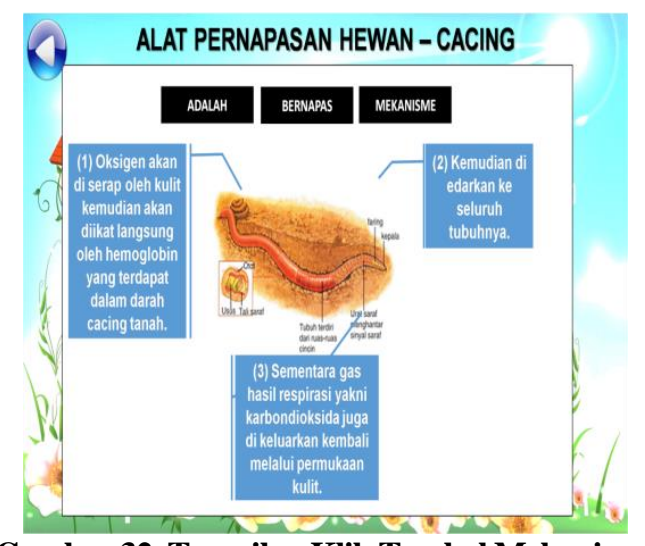

Gambar 32. Tampilan Klik Tombol Mekanisme

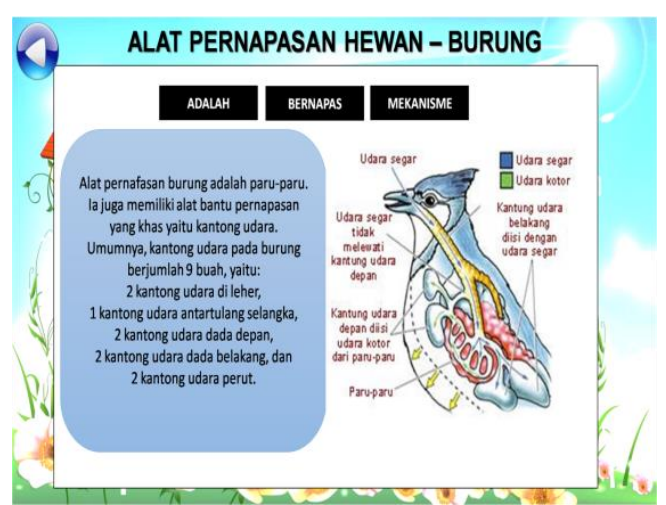

Gambar 34. Tampilan KlikTombol Bernapas

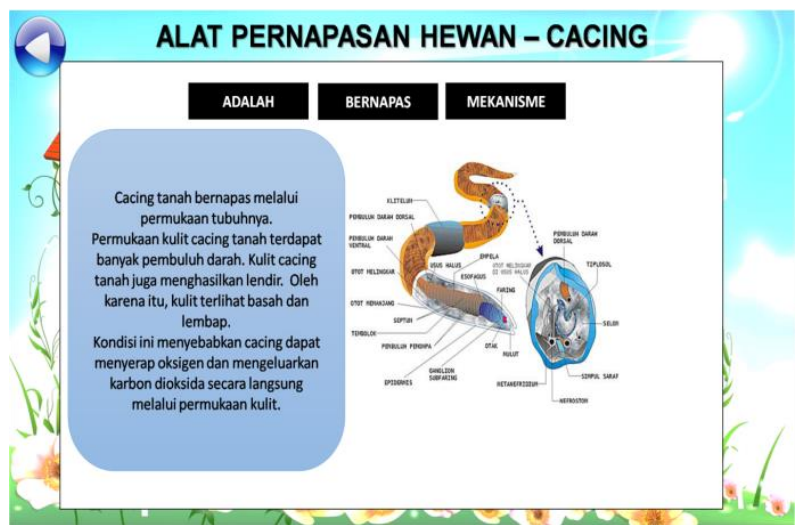

Gambar 31. Tampilan Klik Tombol Bernapas

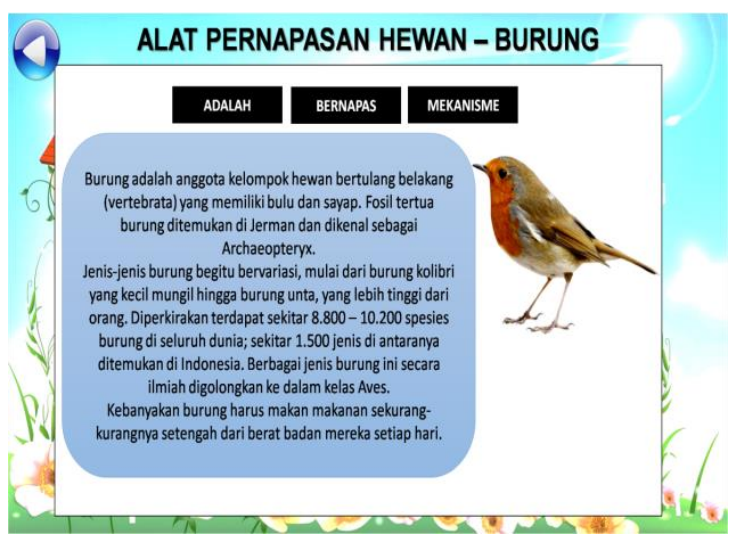

Gambar 33. Tampilan Klik Tombol Burung

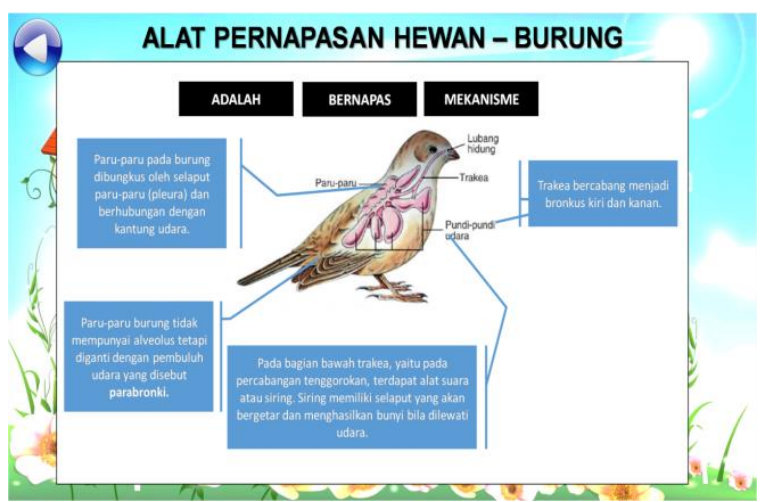

Gambar 35. Tampilan Klik Tombol Mekanisme

\subsubsection{Halaman Game Dan Quiz}

Tampilan form, jika user klik tombol game dan quiz pada halaman utama program (gambar 8), tersaji pada gambar 36 . 


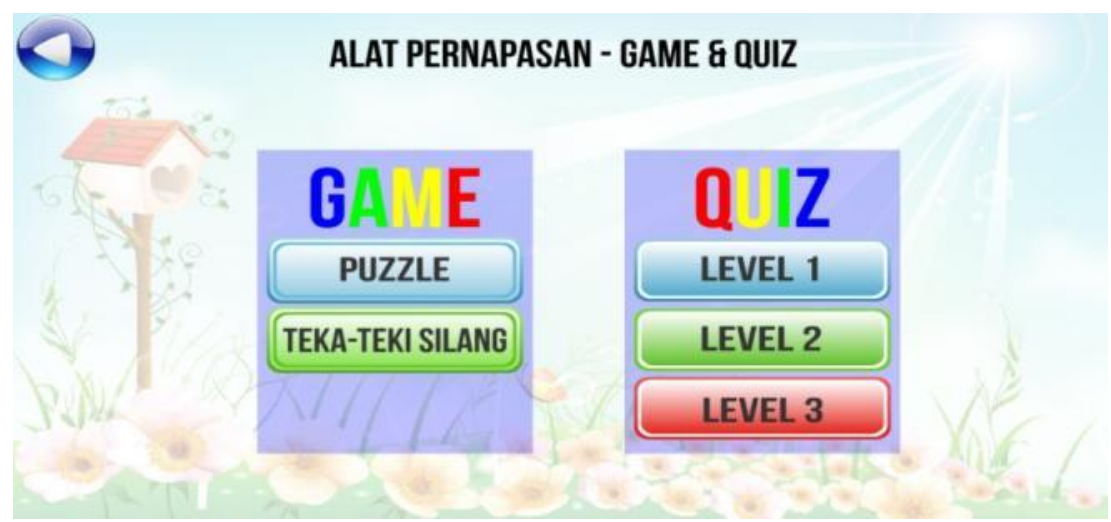

Gambar 36. Tampilan Halaman Menu Game dan Quiz

Untuk menarik minat siswa sebagai user, evaluasi untuk mengetahui sejauh mana pemahaman siswa terkait materi pembelajaran sistem pernapasan yang disajikan di form sebelumnya, disajikan dalam bentuk game puzzle dan teka teki silang yang tersaji di gambar 37 sampai dengan gambar 39. Setiap penyelesaian game dibatasi oleh waktu, yang sebelumnya diatur oleh user.

Sedangkan untuk quis dibagi menjadi tiga level yang disajikan dalam gambar 40 sampai dengan gambar 42. Tingkat level menunjukkan tingkat kesulitan pertanyaan yang diajukan. Masing-masing level terdiri dari 10 soal. Penyelesaian tiap soal dibatasi oleh waktu yang sudah ditentukan oleh user. User tidak bisa kembali ke soal sebelumnya, namun user dapat mengerjakan kembali soal tersebut dengan pertanyaan yang disajikan secara acak oleh sistem. Diakhir game maupun quiz disajikan pembahasan penyelesaian soal.

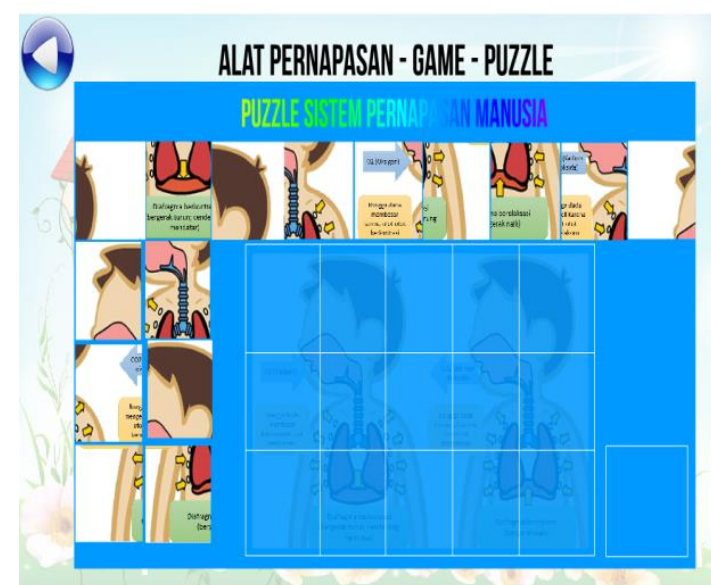

Gambar 37. Tampilan Game Puzzle

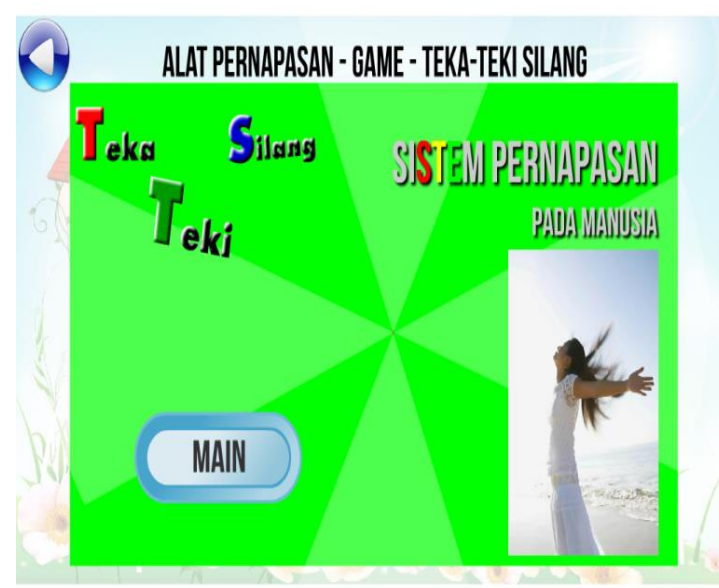

Gambar 38. Tampilan Game TekaTeki Silang

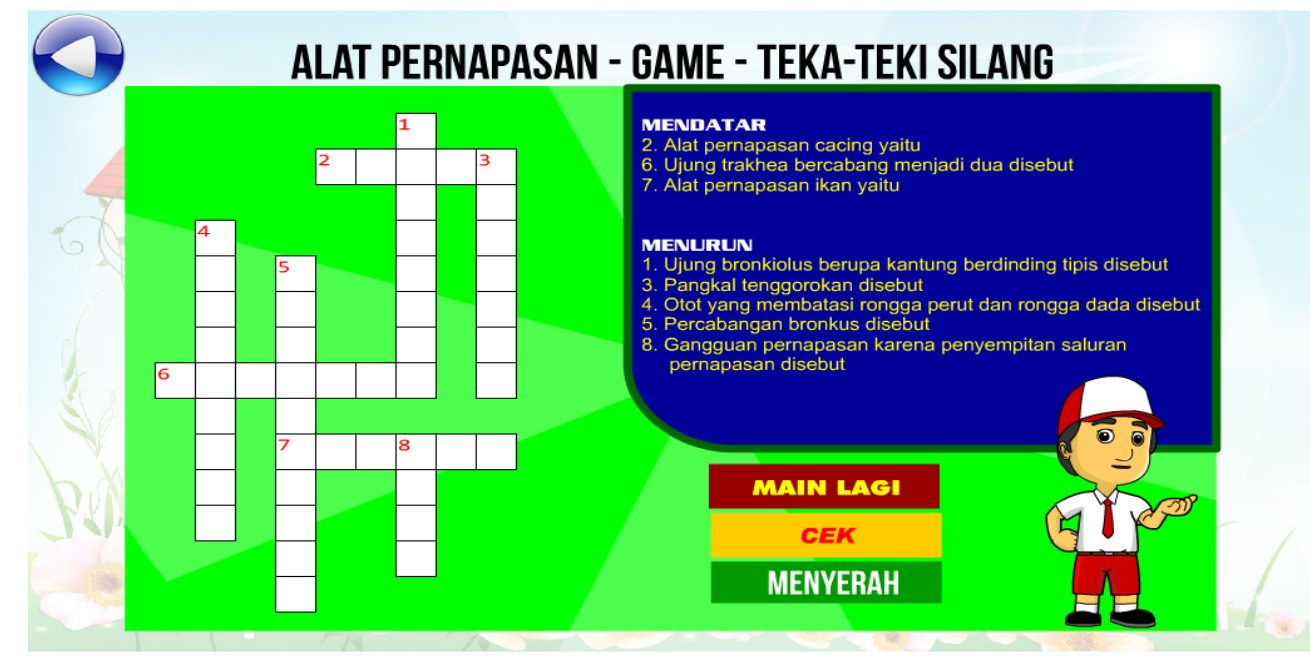

Gambar 39. Tampilan Utama TekaTeki Silang 


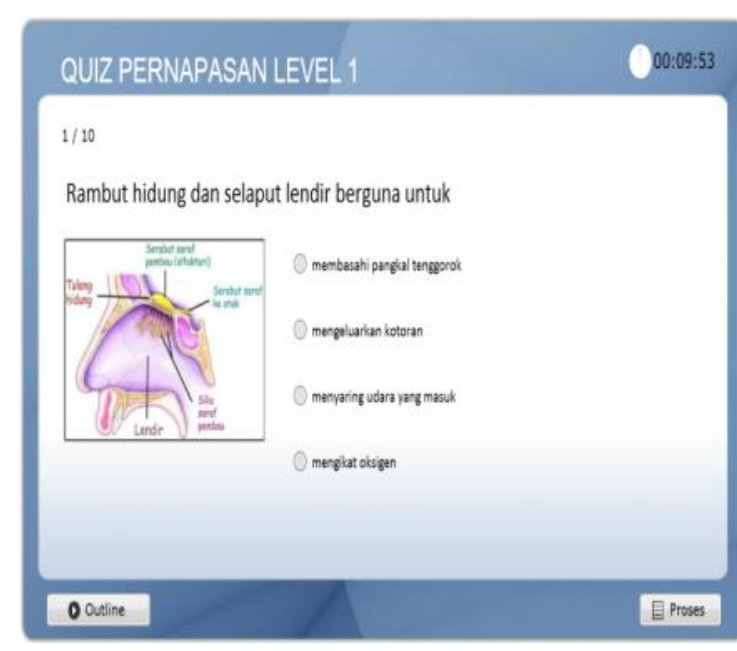

Gambar 40. Tampilan Quiz Level 1

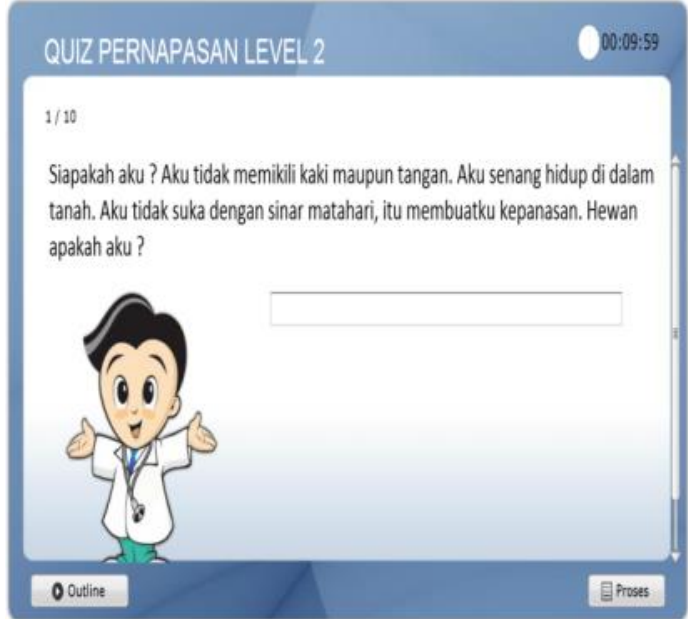

Gambar 41. Tampilan Quiz Level 2

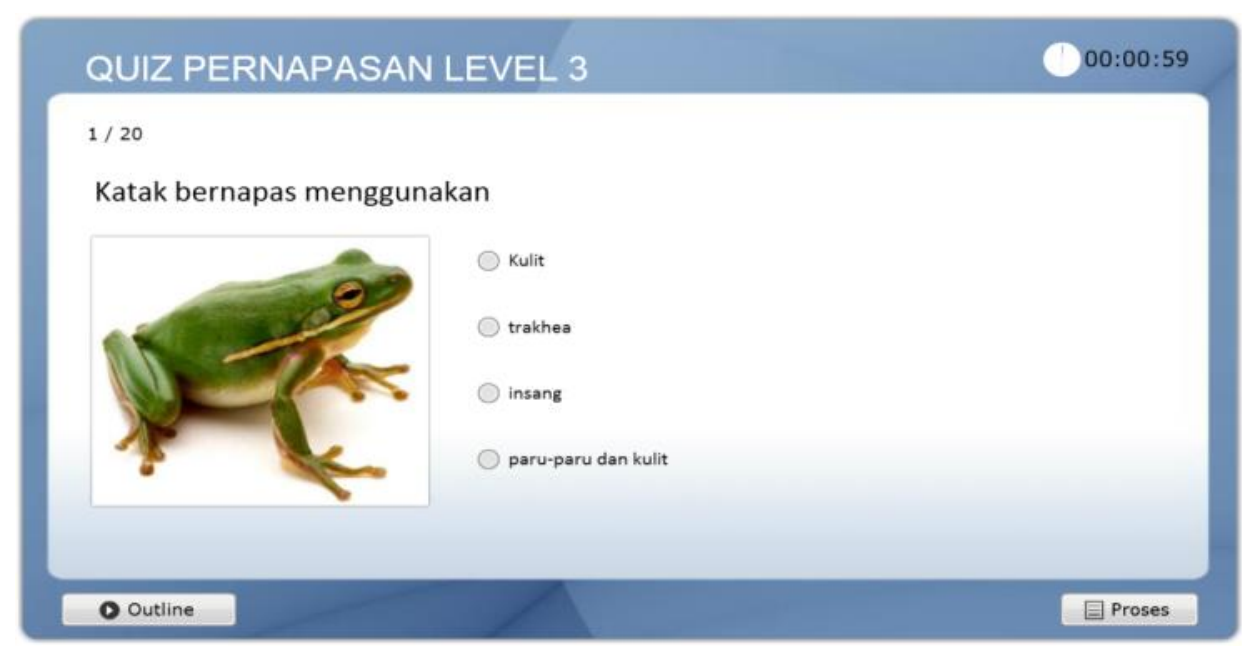

Gambar 42. Tampilan Quiz Level 3

\section{KESIMPULAN}

Anak Berkebutuhan Khusus (ABK) dalam pembelajaran materi IPA/Sains membutuhkan penjelasan materi dalam bentuk visual. Karena sistem pernafasan manusia maupun hewan sangat kompleks dan rumit untuk dijelaskan secara konvensional (dengan gambar) oleh guru pengajar, maka untuk mengatasi hal tersebut yaitu dengan pembangunan program aplikasi berbasis multimedia yang menyajikan materi tersebut dengan visual animasi dan difasilitasi dengan adanya bahasa isyarat. Dalam penelitian ini menghasilkan rancangan sistem maupun interface program yang baik sesuai dengan kebutuhan user.

\section{UCAPAN TERIMA KASIH}

Terima kasih penulis sampaikan kepada BP3IPTEK Provinsi Jawa Barat yang mendanai penelitian ini dalam Program Kegiatan Penigkatan Kualitas Penelitian Dosen PTS/N Dan Politeknik Untuk Pembanguan Jawa Barat Tahun 2016.

\section{DAFTAR PUSTAKA}

[1] Wiyono, K. dkk. 2009. "Model Pembelajaran Multimedia Interaktif Realtivitas Khusus untuk Meningkatkan Penguasaan Konsep, Keterampilan Generik Sains dan Keterampilan Generik Sains Siswa SMA". Jurnal Penelitian Pendidikan IPA, 3 (1). 21-30.

[2] Rusman. 2009. Teknologi Informasi dan Komunikasi dalam Pembelajaran. Bandung: Universitas Pendidikan Indonesia.

[3] Wiyono, K. dkk. 2012. "Model Multimedia Interaktif Berbasis Gaya Belajar Untuk Peningkatkan Penguasaan Konsep Pendahuluan Fisika Zat Padat". Jurnal Penelitian Pendidikan Fisika,8. 74-84. 
[4] Finkelstein, N.D. et al. 2006. HighTech Tools for Teaching Physics: The Physics Education Technology Project. MERLOT Journal of online Learning and Teaching, 2 (3): 110-121.

[5] Effendi, Diana., Learning Application Using Multimedia For $5^{\text {th }}$ Graders Elementary School Student about "Photosynthesis in Plants". Proceding The $1{ }^{\text {st }}$ Sriwijaya University Learning and Education International Conference (SULE-IC). ISBN: 987-602-70378-0-9, pp.927-934, Mei. 2014.

[6] Effendi, Diana., Program Aplikasi Pembelajaran IPA MAteri Sistem Peredaran Darah Manusia untuk Siswa Kelas V SDLB Bagian B (Tuna Rungu) Berbasis Multimedia, Prosiding SNETE ke-4 Jurusan Teknik Elektro Universitas Unsyiah Banda Aceh, ISSN: 2088-9984, pp.5-10, Agustus, 2014.

[7] Effendi, Diana., Hardiyana, Bella., Cahyana, Yayan. Laporan Akhir IbM SDLB Bagian B, 2014. 